\title{
The 2013 Italian Parliamentary election: Changing things so everything stays the same
}

\section{Background}

The previous Italian parliamentary election of 2008 awarded the centre-right coalition led by Silvio Berlusconi with an unprecedentedly large majority in both the Chamber (54.6 percent of seats) and the Senate (55.2 percent). On paper this could stand as the "most cohesive government coalition in the history of the Second Republic" (Chiaramonte and D'Alimonte 2012: 262). On these bases, the Fourth Berlusconi cabinet was generally expected to be stable and durable. Yet this proved not to be the case due to a number of concurrent factors.

From a parliamentary point of view, a major blow came in 2010 with the defection of a significant number of MPs led by Chamber of Deputies' president and Popolo della Libertà (PdL) co-founder Gianfranco Fini. The governing coalition - until then able to maintain its electoral support in both the European election of 2009 and the regional elections of $2010-$ began to lose ground also among the voters. This was especially evident in the local elections and the four abrogative referendums held in the spring of 2011 (on this point, see: Chiaramonte and D'Alimonte 2012).

In the meantime, the international economic crisis was significantly worsening. As a result of the aggravation of the Greek situation, the financial markets grew increasingly skeptical of the sovereign debt of Southern European countries. Italy got immediately in the focus of financial markets, as testified by the massive growth of the spread (i.e., the difference in terms of interest rate paid to investors by the decennial German bonds and Italian BTPs). 
The combination of a weak government and a weakening economic situation fostered the perception that only a cabinet of national unity could face the course of events (ibid.).

It is against this background that the Chamber of Deputies was called on November $8^{\text {th }}$, 2011 to vote on a relatively unimportant budget bill as a means to test the strength of Berlusconi's parliamentary majority. Only 308 MPs (i.e., less than 50 percent) voted in favor. The very same day, Silvio Berlusconi announced his intention to resign right after the approval of the financial stability law. President of the Republic Giorgio Napolitano received the official resignation on November $12^{\text {th }}$ and the very same day invited Senator Mario Monti to form a national unity government aimed at saving the country from the Eurozone sovereign debt crisis. The Monti government - a technocratic cabinet composed entirely of unelected professionals and intellectuals - was presented on November $16^{\text {th }}$. With the support of all parties represented in parliament except Lega Nord, both the Senate and the Chamber passed motions of confidence in support of Monti's government on November $17^{\text {th }}$ and $18^{\text {th }}$ respectively.

Overall, Mario Monti's cabinet succeeded in its goal of putting under control the financial situation of the country and restoring the financial markets' confidence in the Italian debt. Throughout 2012, the spread between German and Italian bonds went progressively down and eventually stabilized below the critical value of 300. In spite of its success in terms of public finance and international reputation, by the end of 2012 the Monti cabinet lost the support of its largest parliamentary party (Silvio Berlusconi's PdL) that abandoned the governing majority on December $6^{\text {th }}$. Two days after, Mario Monti announced that he would resign after the approval of the financial stability law for the year 2013. He did so on December $21^{\text {st }}$, just one day before the dissolution of the XVI legislature and the call for new elections. 
Among the issues that the Monti cabinet was unable to tackle, it must be highlighted the reform of the electoral system. As a matter of fact, the declared willingness of all parties to replace the current electoral law did not result in a sufficiently large consensus on any of the potential alternatives on the table.

\section{Parties and Candidates}

The electoral system-driven mechanism of awarding the absolute majority of seats to the party (or parties) able to gain the relative majority of votes provides strong incentives to the formation of pre-electoral coalitions (for a better discussion of the Italian electoral law, see: Newell 2006; Wilson 2009). The first coalition that takes shape is the centre-left Italia Bene Comune (Italy Common Good), comprising Partito Democratico (PD), Sinistra Ecologia e Libertá (SEL), and Partito Socialista Italiano (PSI). The coalition was launched on October $13^{\text {th }}$ along with the call for open primary elections to nominate the coalition's candidate to the premiership in the subsequent general election. The two-round election saw the victory of PD's leader Pier Luigi Bersani over Matteo Renzi with $61 \%$ of votes in the run-off held on December $2^{\text {nd }}$. The primary elections proved to be a good moment for the centre-left, with extremely high visibility in the media (due, most notably, to the two candidates' debates broadcasted in prime time by national televisions SKY and Rai1) and good return in terms of electoral polls, with the centre-left coalition comfortably above 40 percent in the beginning of December (see Figure 1).

The remarkable figure for the centre-left in the polls needs however to be contextualized within a generalized lack of clear political contenders for the time being. The first one to make an official step ahead is incumbent prime minister Mario Monti who, on the night of Christmas, announced on Twitter his willingness to 'ascend to politics'. Monti's list Scelta Civica (SC) was officially presented on January $4^{\text {th }}$. Entirely composed of non-political 
figures coming from civil society, it joined an electoral alliance led by Mario Monti (comprising also Pierferdinando Casini's UDC and Gianfranco Fini's FLI). To many observers, the implicit strategy of Monti was that of becoming an indispensable governing partner for the by-then winner in pectore Pierluigi Bersani.

Only a few days later, on January $7^{\text {th }}$, Silvio Berlusconi confirmed his intention to run in the forthcoming election. On that day, he announced a coalition agreement between the PdL and Roberto Maroni's Lega Nord (LN). The agreement entailed the PdL's support to Maroni's bid for the presidency of Lombardy as well as the unprecedented position of Silvio Berlusconi as potential Minister of the Economy rather than candidate for the premiership. Berlusconi retained nonetheless the position of 'leader of the coalition'.

In the meantime, another key political player was getting ready to compete in its first general election: the Movimento 5 Stelle (M5S) led by comedian and political activist Beppe Grillo (for a detailed description of history and development of the M5S, see: Bordignon and Ceccarini 2013). His movement has been present on the Italian political scene since 2008, when its first members got elected in local councils under the denomination of 'friends of Beppe Grillo'. However, it was only in 2009 that the M5S was formally established. The following years saw growing electoral success for the movement, which scored more than 5 per cent of the votes in the regional elections of 2010 and approached ten per cent in the local elections of 2011. The local elections of 2012 marked the breakthrough of the M5S which reached two-digit vote shares in almost half of the municipalities where it was running (ibid.) and elected mayors in four municipalities including the city of Parma. This stunning success further broadened the popular support for the movement, as confirmed by the regional election of Sicily where the M5S gained about 15 per cent of the votes and became the strongest party in the island. With the general election approaching, polls confirmed this trend on a national basis (see Figure 1). 
Other players in the 2013 election include the antagonist left, this time represented in by Rivoluzione Civile (RC), a new formation led by celebrity magistrate Antonio Ingroia and supported by a constellation of small parties of the extreme left, the federation of the greens as well as Antonio Di Pietro's Italia dei Valori (IdV).

\section{The campaign}

In line with the mediatization trend common to all advanced industrial democracies, the campaign took place mostly in the media - with television playing a major role. As in 2008 , no leaders' debate took place due to a number of cross-vetoes and a generalized disagreement on how many leaders were supposed to take part in the debate. Party leaders enjoyed nonetheless a high visibility in the traditional media. This was especially the case for Berlusconi and Monti, while Bersani's strategy of de-personalizing the campaign message (as testified, among others, by the exclusion of his name from the party symbol) resulted in a significantly lower coverage (ComPol, 2013). Grillo was also underrepresented in news coverage, partly due to the inherently internet-based nature of the M5S but also because of his leader's open aversion for traditional Italian media (which were not even allowed to film his rallies in proximity of the stage).

According to many observers, the event that marked the beginning of the actual campaign is Silvio Berlusconi's appearance in Michele Santoro's talk show Servizio Pubblico on January $10^{\text {th }}$ In this occasion, Berlusconi acted aggressively and already hinted at the strategy he then pursued with vigor throughout the campaign: extensive presence in the media dressed with 'shock' proposals in order to remobilize his traditional base of supporters

Generally speaking, Berlusconi's campaign was characterized by reliance on his traditional political marketing repertoire. Not unlike other campaigns, he made extensive use of his own football team. On January 29th A.C. Milan formalized the acquisition of Italian 
national team's striker Mario Balotelli from Manchester City. The political purpose of this move was implicitly explained by Berlusconi himself, who declared that 'it was absolutely NOT an election campaign investment ... I acquired Balotelli because I thought: he scored two goals against Germany and made Germans cry, while the other Mario, Monti, scored two goals as well but made Italians cry instead' (Tg3, January 29th). According to a poll conducted by SWG (2013) the acquisition of Balotelli resulted in an electoral gain for PdL of 0.3 percentage points. Indeed, a potentially stronger (yet unmeasured, due to the legally imposed 'black-out' of polls in the two weeks preceding the election) electoral effect came from Berlusconi's proposal of refunding the property tax (IMU) paid by all house owners in 2012. On February $19^{\text {th }}$ millions of Italians received in their mailbox a letter in which Berlusconi explained that in order to receive the refund they should vote for the PdL on February 24-25.

In the meantime, the already non-remarkable campaign of PD had to face the Monte dei Paschi scandal, for which it was held responsible by a substantial proportion of Italians due to the heavy connection between the functioning of the bank and the political dynamics of the municipality of Siena - a historical stronghold of the centre-left. The short-term effect of the scandal has been quantified in a loss of two percentage points for the coalition led by Bersani (SWG 2013). From a symbolic point of view, the centre-left was charged with the accusation of 'forgetting' its popular roots, as exemplified by the controversial decision to hold the last rally of the campaign behind closed doors (i.e., the small Ambra Jovinelli theater in Rome) rather than in Piazza San Giovanni - the historical location of the Italian left. This decision was further debated in the light of the immense success enjoyed in that square on the same night by Beppe Grillo's M5S rally, which marked the end of his hugely popular 'Tsunami Tour' featuring appearances in over a hundred Italian cities. 
The campaign dynamics are well exemplified in the trends of daily polls presented in Figure 1. Survey evidence highlights the initial lead of Bersani's coalition as a result of the primary elections (above 40 percent in the first weeks of December). As said, the progressive decline of the centre-left throughout time can be ascribed in part to its weak campaign strategy. However, the entrance of other contenders in the contest must be taken into account as well. Monti's coalition grew substantially during the holidays, while Berlusconi's upsurge started right after then. Nevertheless, on February $8^{\text {th }}$ (i.e., the last day before the black-out of polls) the centre-left coalition still seemed to enjoy a relatively safe margin of 5 percentage points on Berlusconi's centre-right coalition. On these bases, the general perception among the electorate was a more or less clear victory for the coalition led by Pier Luigi Bersani. Electoral experts were however slightly more skeptical. According to D’Alimonte (2013), 'Mr Berlusconi's chance of increasing his share of the vote are limited - but Mr Bersani's chances of decreasing his are not. If polls do not lie, the present leads should be safe. But ... polls may lie to some extent.'

Already in 2006 did pollsters fail to predict the final outcome of the election (Newell 2006). A number of context-specific factors made even more likely the possibility of failure with respect to the 2013 election. The extremely high number of late deciders must be highlighted: 48 hours before the opening of the polls, over ten per cent of voters declared themselves undecided (Diamanti 2013a). Moreover, and unlike 2006, the multi-polar structure of the competition in 2013 made extremely difficult to predict how the late deciders would have reacted. Most notably, the presence of Grillo offered them with a valid alternative to abstention.

\section{The result}


The 2013 election highlighted for the first time in the history of Italian parliamentary elections the participation below 80 per cent of eligible voters, the actual turnout figure being 75.2 percent. Due to the extremely complicated nature of the current electoral system - which entails among others different thresholds for the two chambers (4\% in the Chamber, $8 \%$ in the Senate), two different ways of awarding the majority bonus (on a national and a regional basis respectively), and a different voting population (all voters younger than 25 can only cast a vote for the Chamber) - it is worth discussing the result for each chamber in turn.

According to the current regulations, an absolute majority of seats (55 percent) in the Chamber is awarded to the party (or coalition) gaining the relative majority of votes. Albeit with a much smaller margin than forecasted, the winning coalition was the centre-left led by Pier Luigi Bersani (29.6 percent). Berlusconi's centre-right gained 29.2 percent of the votes, while incumbent Prime Minister Mario Monti's coalition scored only a modest 10.6 percent. The biggest surprise was Beppe Grillo's M5S with 25.6 percent of the votes - making it the strongest individual party and the third political force in the country. As in 2008, the extreme left was unable to overcome the $4 \%$ threshold and did not gain parliamentary representation.

$<$ Table 1 about here>

The crucial result, however, came from the Senate. Similarly to the Chamber, the centre-left gained in the Senate about 200.000 votes more than the centre-right, but won only 123 seats (39 percent) due to the regionally-based attribution of the majority bonuses. The centre-right won 117 seats (37.1 percent) while Grillo's movement got elected 54 senators (17.1 percent). In the face of these numbers, the unwillingness of M5S to take part in any postelection coalition as well as the poor result of the Monti-led alliance (only 6 percent of the 
seats) result in the impossibility to form any parliamentary majority without the consent of both PD and PdL.

A comparison with the results of 2008 highlights the magnitude of the defeat on behalf of the two major Italian parties (for a more detailed analysis, see Passarelli and Tuorto 2013). The PD lost about 30 percent of the votes almost uniformly throughout the country but with stronger peaks in the southern regions (-37 percent). Even worse was the performance of the PdL, which lost in five years more than 6 million votes (-46 percent). These extremely poor results can be imputed to the inability of these parties to both remobilize their core voters and/or attract new ones. According to Vezzoni (2013), only 44 percent of centre-right voters in 2008 confirmed their vote to the centre-right in 2013; this figure is slightly higher in the case of the centre-left (58 percent). As for their ability to attract new voters, only 13 percent of centre-right voters in 2013 did not vote for it in 2008 (the figure for the centre-left is 18 percent).

The lack of attractiveness of the main coalitions represents in turn one of the keys to understand the success of M5S. Preliminary evidence found that roughly two thirds of the votes gained by Grillo's movement came (in relatively equal measure) from former voters of the two main coalitions (Demos 2013). The territorial factor is very important: the support of the M5S is in fact substantially uniform across the country whereas the main coalitions lost more votes exactly where they used to be stronger (Boeri and Nannicini 2013). The M5S did not only fish into the traditional geographical bowls of established parties, but also among the social bases of their consensus. As pointed out by Diamanti (2013b) a wide majority of voters 'on the run' belonging respectively to the historically aligned productive sectors (entrepreneurs and autonomous workers for the centre-right, white collars and professionals for the centre-left) resorted indeed to the M5S. 
The main coalitions maintained their strength only amongst the unproductive strata of the population (housewives for the centre-right and pensioners for the centre-left), whereas the electorate of the M5S shows a clear dominance of younger voters. The M5S would appear to be the only political force whose support comes for less than $50 \%$ (i.e., $43 \%$ ) from people younger than 45 years-old - the figure for centre-right and centre-left being 60 and 65 percent respectively (Vezzoni 2013).

\section{The aftermath}

The problematic nature of the electoral outcome resulted in a correspondingly long process of government formation that took over 2 months. This formally started three weeks after the election, on March 20th, when the President of the Republic initiated the consultations with the parliamentary groups. As a result, an exploratory mandate was given to the leader of the party controlling the absolute majority of the Chamber. Pierluigi Bersani, however, found himself unable to secure an absolute majority in the Senate in support of his premiership. It became immediately clear that the main parties' strategy was that of linking the choice of the name of the new premier to the forthcoming election of the new President of the Republic. On April 20th, incumbent President Giorgio Napolitano, holder of the post since 2006, eventually agreed to run for another term in an attempt to break the parliamentary deadlock. The wide majority of votes that supported his re-election represented somehow the solution to the ongoing negotiation between the parties originally supporting the Monti government. On April 28 ${ }^{\text {th }}$ Napolitano appointed PD's deputy party leader, Enrico Letta, at the head of another unity government involving political personalities from PD, PdL and SC. The extent to which this government will be able to last in time remains to be seen. Nonetheless, Prime Minister Enrico Letta made clear the political connotation of his government by openly pointing (already in his inaugural address) to a time horizon of years rather than months. However, 
such an attempt does not entirely eradicate the widespread perception of the new government as a sort of follow-up to the previous one led by Mario Monti. Indeed, the parties supporting Letta's government are virtually the same and so remain the differences among coalition parties in terms of policy positions over several key issues. In the long run, this is likely to provide ground for Beppe Grillo's movement to grow further in electoral terms, with established parties behaving as forecasted by the M5S leader and, in doing so, fostering the perception of changing things so everything stays the same.

\section{Conclusions}

The Italian election of February 2013 was held in the context of a generalized erosion of consensus for established parties across the continent (Dinas and Rori, 2013; Quinn, 2011). Its peculiarity, however, lies in the fact that such erosion was so vast in magnitude to even challenge the established pattern of bipolar competition to which the country was used to since 1994. The composition of the new parliament highlights a system of three equally powerful extremes, the respective size of which prevents the formation of any political majority without the consent of at least two of the three main political players.

As in 2006, the expected comfortable victory of the centre-left did not materialize as it won by an extremely small margin of votes vis-à-vis the centre-right. Unlike 2006, however, such victory occurred in a truly tri-polar context - a context in which a relative majority of votes does not necessarily correspond to an absolute majority of seats in both parliamentary branches. The driver of change was clearly Beppe Grillo's M5S which, according to many observers, represents the real winner of the 2013 election. Indeed, the movement confirmed the steady upward trend of the last years by gaining about 25 percent of the popular vote. Such result is likely to bear a strong impact on the patterns of political competition in the country. The M5S represents the biggest challenge so far to the system's bipolar dynamic by 
its ability to attract voters from the territorial and social bases of all political camps and from the growing group of non-voters.

As for the PD, it is quite hard not to consider it the biggest loser of the 2013 election. In spite of having gained a relative majority of the votes and the absolute majority of seats in one chamber, the PD lost the chance - with which it was so widely credited throughout the campaign - to win and govern alone. Bersani's deliberate choice to depersonalize the campaign was possibly crucial in this respect. Indeed, the failure of the PD campaign can be interpreted as a further testimony of the longstanding lack of understanding on behalf of the Italian left of the importance of personalization when it comes to voters' behavior. The unexpected electoral success of Berlusconi's PdL further strengthens this contention. Through his aggressive and highly personalized campaign, he got (once more) extremely close to winning the majority of seats in the Chamber. As in 2006, part of such success is to be attributed to Berlusconi's extensively popular position on the tax issue and in particular on the property tax (IMU). However, a more comprehensive account of the election result cannot avoid taking into account the blend of rational issues and personal charisma that surrounds Silvio Berlusconi's political success in the last two decades (Bellucci et al. 2013). Through the personal return in the media field, and the sudden re-emergence of his party, Berlusconi proved wrong those (see, e.g., Fabbrini 2012) who enthusiastically believed that the technicalities of policy could permanently harm the personalization of politics.

\section{References}

Bellucci, Paolo, Diego Garzia, and Michael S. Lewis-Beck (2013). 'Issues and leaders as vote determinants: The case of Italy', Party Politics, DOI: 10.1177/1354068812472583.

Boeri, Tito, and Tommaso Nannicini (2013). 'Come il voto ha cambiato i partiti', lavoce.info, 12 March. <http://www.lavoce.info/voto-cambiament-partiti-m5s-beppe-grillo-pd-pdlmonti/> 
Bordignon, Fabio, and Luigi Ceccarini (2013). 'Five Stars and a Cricket. Beppe Grillo Shakes Italian Politics', South European Society and Politics, DOI:10.1080/13608746.2013.775720

Chiaramonte, Alessandro, and Roberto D'Alimonte (2012). 'The Twilight of the Berlusconi Era: Local Elections and National Referendums in Italy, May and June 2011', South European Society and Politics, 17:2, 261-79.

ComPol (2013). 'La campagna elettorale 2013 sui media: Ambienti a confronto', Associazione Italiana di Comunicazione Politica. <http://www.compol.it/r/campagna-media-2013/> D'Alimonte, Roberto (2013). 'How Berlusconi could yet pull off the unimaginable', Financial Times, 14 February.

Demos (2013). 'La terza ondata del voto grillino', 7 March, <http://www.demos.it/a00830.php>.

Diamanti, Ilvo (2013a). 'Per uno su dieci il voto è last-minute', La Repubblica, 24 February.

Diamanti, Ilvo (2013b). 'Destra e sinistra perdono il proprio popolo. M5S come la vecchia Dc: interclassista', La Repubblica, 11 March.

Dinas, Elias, and Lamprini Rori (2013). 'The 2012 Greek Parliamentary Elections: Fear and Loathing in the Polls', West European Politics, 36:1, 270-82.

Fabbrini, Sergio (2012). 'The rise and fall of Silvio Berlusconi: Personalization of politics and its limits', Comparative European Politics, 11: 2, 153-71.

Newell, James (2006). 'The Italian Election of May 2006: Myths and Realities', West European Politics, 29:4, 802-13.

Passarelli, Gianluca, and Dario Tuorto (2013). 'Chi ha vinto, chi ha perso, e dove', Analisi dell'Istituto Carlo Cattaneo, 26 February. <http://www.cattaneo.org/it/pubblicazionimenu/comunicati-menu>

Quinn, Thomas (2011). 'From New Labour to New Politics: The British General Election of 2010', West European Politics, 34:2, 403-11.

SWG (2013). 'Mps si abbatte sul Pd $(-1,4)$, effetto Balotelli sul Pdl $(+2,1)$ ', The Huffington Post, 1 February. <http://www.huffingtonpost.it/2013/02/01/elezioni-2013-sondaggio-swgmps-si-abbatte-sul-pd--14-effetto-balotelli-sul-pdl-21_n_2596766.html>

Vezzoni, Cristiano (2013). 'The lost charm of the major coalitions', paper presented at the "Italian politics 2013: Election experts analyze the results" conference, New York University, Florence.

Wilson, Alex (2009). 'The Italian Election of April 2008: A Political Earthquake?', West European Politics, 32:1, 215-25. 
Figure 1. Trends in daily polls (1 December 2012 - 8 February 2013)

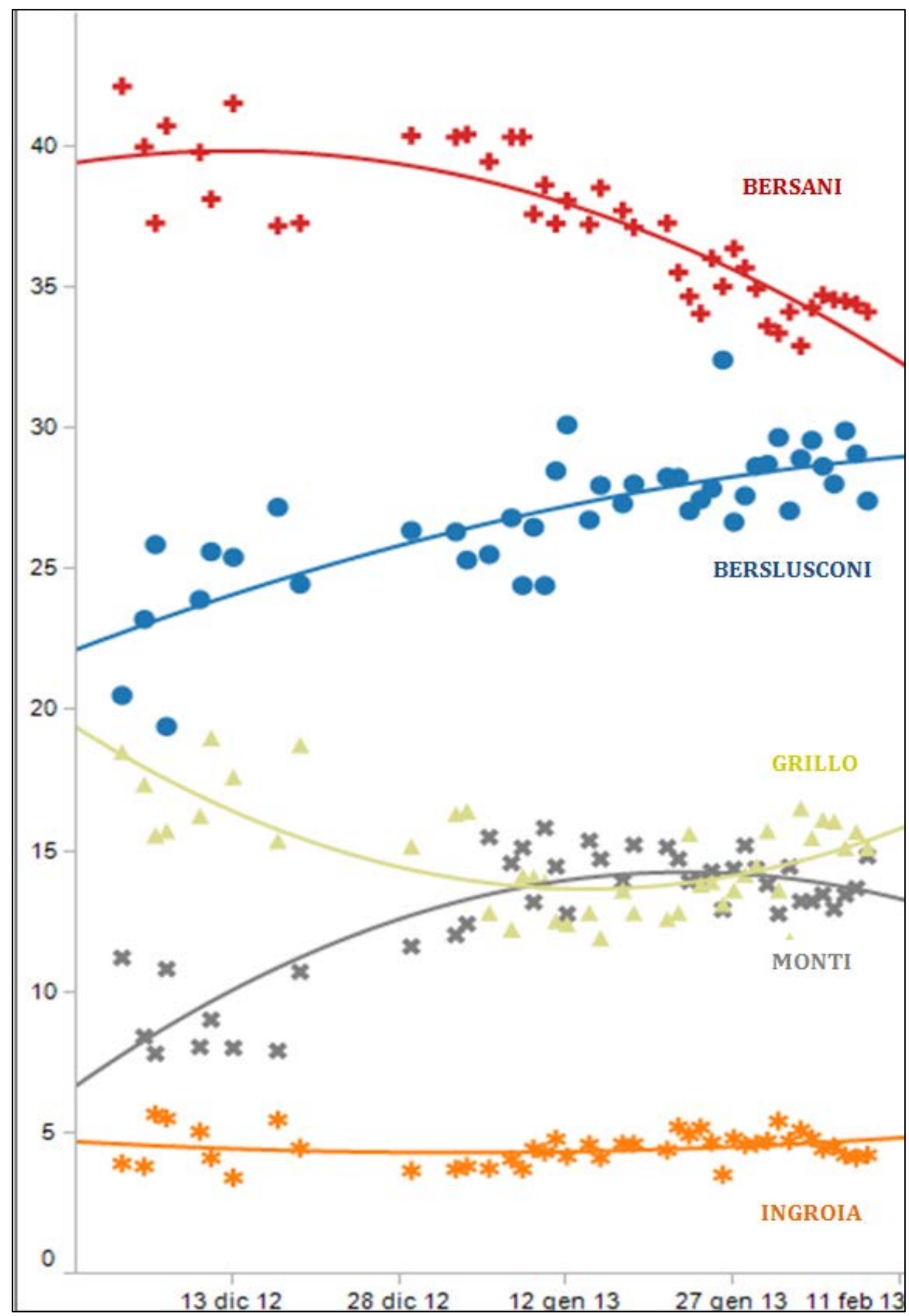

Source: http://www.termometropolitico.it/sondaggi 
Table 1. Chamber of Deputies Election Results 2008 and 2013

\begin{tabular}{|c|c|c|c|c|c|c|}
\hline & & 2013 & & & 2008 & \\
\hline & $\begin{array}{c}\text { Seats } \\
\mathrm{N}\end{array}$ & $\begin{array}{l}\text { Votes } \\
\text { (000's) }\end{array}$ & $\begin{array}{c}\text { Votes } \\
\%\end{array}$ & $\begin{array}{c}\text { Seats } \\
\mathrm{N}\end{array}$ & $\begin{array}{l}\text { Votes } \\
\text { (000's) }\end{array}$ & $\begin{array}{c}\text { Votes } \\
\%\end{array}$ \\
\hline MoVimento 5 Stelle (M5S) & 109 & 8,689 & 25.55 & - & - & - \\
\hline Partito Democratico (PD) & 297 & 8,644 & 25.42 & 211 & 12,095 & 33.18 \\
\hline Il Popolo della Libertà (PdL) & 98 & 7,332 & 21.56 & 272 & 13,629 & 37.38 \\
\hline Scelta Civica (SC) & 39 & 2,824 & 8.30 & - & - & - \\
\hline Lega Nord (LN) & 18 & 1,390 & 4.08 & 60 & 3,024 & 8.30 \\
\hline Sinistra Ecologia Libertà (SEL) & 37 & 1,089 & 3.20 & - & - & - \\
\hline Rivoluzione Civile (RC) & 0 & 765 & 2.25 & - & - & - \\
\hline Fratelli d'Italia (FdI) & 9 & 665 & 1.95 & - & - & - \\
\hline Unione di Centro (UdC) & 8 & 608 & 1.78 & 36 & 2,050 & 5.62 \\
\hline Fare per Fermare il Declino (FARE) & 0 & 380 & 1.11 & - & - & - \\
\hline Centro Democratico (CD) & 6 & 167 & 0.49 & - & - & - \\
\hline Südtiroler Volkspartei (SVP) & 5 & 146 & 0.43 & 2 & 147 & 0.41 \\
\hline Italia dei Valori & - & - & - & 28 & 1,594 & 4.37 \\
\hline La Sinistra - L'Arcobaleno & - & - & - & 0 & 1,124 & 3.08 \\
\hline La Destra-Fiamma Tricolore & 0 & 219 & 0.64 & 0 & 884 & 2.43 \\
\hline TURNOUT & & & 75.17 & & & 80.45 \\
\hline
\end{tabular}

